\title{
Identification of a yeast old yellow enzyme for highly enantioselective reduction of citral isomers to $(R)$-citronellal
}

\author{
Liandan Zheng ${ }^{1}$, Jinping Lin ${ }^{1 *}$, Baoqi Zhang ${ }^{1}$, Yuyao Kuang ${ }^{2}$ and Dongzhi Wei ${ }^{1}$
}

\begin{abstract}
Background: A NAD(P)H-dependent enoate reductase (OYE2p) from Saccharomyces cerevisiae YJM1341 was discovered by genome data mining for asymmetric reduction of (E/Z)-citral to $(R)$-citronellal with high enantioselectivity.

Methods: This enzyme was heterologously expressed in E. coli and characterized for its biocatalytic properties. OYE2p was identified with reduction activities toward a diverse range of $a, \beta$-unsaturated compounds bearing conjugated aldehyde, ketone, imide, carboxylic acid and ester.

Results: OYE2p showed the highest specific activity at $40^{\circ} \mathrm{C}$ and a pH optimum at 7.0-8.0. The stability of OYE2p was rather $\mathrm{pH}$-independent, and the half-life time values of the enzyme at $\mathrm{pH} 6.0-8.0$ were more than $257 \mathrm{~h}$. With regard to the reduction of (E)-citral and (Z)-citral, OYE2p exhibited different selectivity patterns. (E)-citral was exclusively reduced to $(R)$-citronellal by OYE2p in $\geq 99 \%$ ee, which was independent on $\mathrm{pH}$. OYE2p produced both enantiomers of citronellal from (Z)-citral, but showed (R)-citronellal formation tendency, and the ee value of (R)-citronellal was affected by $\mathrm{pH}$ in the reaction system. Accordingly, the ee values for $(R)$-citronellal formation increased with the increasing levels of $E$-isomer in the (E/Z)-citral mixture as well as the increase of $\mathrm{pH}$. Under the reaction conditions $\left(30^{\circ} \mathrm{C}\right.$ and $\mathrm{pH}$ 8.6), using purified OYE2p as catalyst, $200 \mathrm{mM}$ (E/Z)-citral (an approximately 10:9 mixture of geometric E-isomer and Z-isomer) was efficiently converted to (R)-citronellal with $88.8 \%$ ee and $87.2 \%$ yield.
\end{abstract}

Conclusion: All these positive features demonstrate high potential of OYE2p for practical synthesis of (R)-citronellal and in asymmetric reduction of activated alkenes.

Keywords: Enoate reductase, Old yellow enzyme (OYE), Citral, (R)-Citronellal, Enantioselectivity, Asymmetric reduction

\section{Background}

Citronellal, i.e., 3,7-dimethyl-6-octenal, contains a chiral carbon atom and thus has both $(R)$ - and $(S)$-configurations. Citronellal has a strong aroma of green citrus and a mild smell of woody, which is widely used in fragrance industry (Lenardao et al. 2007). Comparing to (S)-enantiomer, $(R)$-citronellal is more valuable, and it is a particularly useful intermediate for the synthesis of L-menthol,

\footnotetext{
*Correspondence: jplin@ecust.edu.cn

${ }^{1}$ State Key Laboratory of Bioreactor Engineering, New World Institute of Biotechnology, East China University of Science and Technology, Shanghai 200237, China

Full list of author information is available at the end of the article
}

one of the world's largest flavoring chemicals (Trasarti et al. 2004).

At present, chemocatalysis was the main method for the production of $(R)$-citronellal, such as chiral $(S)$ BINAP-Rh complex-catalyzed enantioselective isomerization of geranylamine to $(R)$-citronellal in the Takasago process (Tani 1985; Akutagawa 1997), and enantioselective reduction of $(E)$-citral presented by BASF (Bergner et al. 2010). For the former method, the catalyst is quite harsh to prepare and difficult to recover. Prior rectification of $(E / Z)$-citral (a mixture of trans- and cis-isomer) to obtain high-purity $(E)$-citral is needed in the BASF process. Indeed, enantioselective hydrogenation of the low-cost $(E / Z)$-citral provided a straightforward and 
economically attractive process for the synthesis of $(R)$ citronellal. A dual-catalyst system comprising enantiopure 2-diarylmethylpyrrolidines and heterogeneous $\mathrm{Pd} /$ $\mathrm{BaSO}_{4}$ was developed for the asymmetric hydrogenation of citral to afford $(R)$-citronellal. However, the enantioselectivity was insufficient ( $89 \%$ ee) (Maeda et al. 2012). So far, there is no organocatalyst to yield only $(R)$-citronellal from crude 3:2 mixture of $(E)$ - and $(Z)$-citral. Due to the presence of multiple $\mathrm{C}=\mathrm{C}$ and $\mathrm{C}=\mathrm{O}$ double bonds, the asymmetric reduction of citral in a chemo-, regio- and stereoselective fashion has been a daunting challenge.

Enoate reductase-mediated catalysis is therefore a promising alternative to classical organic catalysis (Moore et al. 2007; Hollmann et al. 2011; Winkler et al. 2011). Enoate reductases from the old yellow enzyme (OYE) family have been characterized in considerable detail and become practical catalysts for the stereoselective trans-hydrogenation of conjugated $\mathrm{C}=\mathrm{C}$ double bond (Stuermer et al. 2007; Amato and Stewart 2015). Although several enoate reductases for the asymmetric reduction of the crude $(E / Z)$-citral have been reported, most of them showed insufficient enantioselectivity and activity. Also, more enoate reductases preferably produced the $(S)$-citronellal from $(E / Z)$-citral. YqjG from Bacillus stubtilis (Hall et al. 2008), NCR from Zymomonas mobilis (Hall et al. 2010), YersER from Yersinia bercovieri (Yanto et al. 2011), and GYE1 from Gluconobacter oxydans (Richter et al. 2011) even reduced both citral isomers exclusively to $(S)$-citronellal. With regard to the synthesis of $(R)$-citronellal via citral reduction, only XenA from Pseudomonas putida and its mutant XenAC25G were reported to yield exclusive $(R)$-citronellal $(99.5 \% e e)$ from $5 \mathrm{mM}(E / Z)$-citral with conversion of 8.1 and $33.5 \%$, respectively (Yanto et al. 2010). Unexpectedly, in our repetitive trials, they produced only $(S)$-citronellal from $5 \mathrm{mM}(E)$-citral, (Z)-citral or $E / Z$ mixture of citral (an approximately 10:9) with conversion of $8-34.2 \%$ and $\geq 99.5 \%$ ee. Relatively few enoate reductases produced mainly $(R)$-citronellal from both citral isomers, including OYE2.6 from Pichia stipites (Bougioukou et al. 2010), KYE1 from Kluyveromyces lactis (Yanto et al. 2011), OYE1 from Saccharomyces pastorianus, and OYE2 and OYE3 from S. cerevisiae (Müller et al. 2007). These enzymes preferably produced $(R)$-citronellal from $(E)$-citral but both enantiomers from $(Z)$-citral. Among them, OYE2 and OYE2.6 were quite specific in reduction of $(E)$ citral to $(R)$-citronellal with high $e e$ values ( $\geq 98 \%$ ). With almost pure $(E)$-citral, OYE2.6 predominantly produced $(R)$-citronellal, but more (S)-citronellal was formed for OYE2 (Bougioukou et al. 2010; Müller et al. 2007). Accordingly, $50 \mathrm{mM}$ citral (approximately 3:2 mixture of both isomers) was reduced by OYE2.6 to $(R)$-citronellal with about $90 \% e e$. However, if with geometrically pure
$(E)$-citral ( $\geq 98 \%)$ as substrate, up to $150 \mathrm{mM}$ substrate could be reduced to $(R)$-citronellal by OYE2.6 with high $e e$ value of $98 \%$ and high conversion of $95 \%$ (Bougioukou et al. 2010). In that way, to maximize enantioselectivity, prior separation of $E$ - and $Z$-isomer of citral becomes an energetic issue, but it is cost-prohibitive. Therefore, there is still highly desirable to develop more robust enoate reductases with high enantioselectivity toward citral for the synthesis of $(R)$-citronellal.

Herein, we described a newly discovered enoate reductase (OYE2p) from S. cerevisiae YJM1341 capable of efficiently reducing $(E / Z)$-citral to $(R)$-citronellal with high enantioselectivity. The present study provided some indepth characterization of this enzyme, and detailed that enantioselectivity was influenced by the citral isomer ratio and by the reaction $\mathrm{pH}$.

\section{Results and discussion}

\section{Screening of enoate reductases}

A genome mining approach was used to search for enoate reductase that might be able to asymmetrically reduce $(E / Z)$-citral to $(R)$-citronellal. According to the reports that OYE1-3 family proteins were the $(R)$-selective enzymes under proper conditions (Müller et al. 2007; Hall et al. 2010), 11 OYE1 proteins, 26 OYE2p proteins, 13 OYE3p proteins as well as 19 hypothetical proteins owning $\geq 30 \%$ identities of amino acid sequence with functionally known enoate reductase KYE1 from $K$. lactis (Genbank Accession Number: L37452.1) which showed relatively high enantioselectivity $(86 \%$ ee of $(R)$ cirtonellal) (Yanto et al. 2011) were selected from the NCBI database and overexpressed in E. coli BL21 (DE3). After testing their activities toward citral (10:9 mixture of $E$-isomer and $Z$-isomer), five enoate reductases produced mainly $(R)$-citronellal (Table 1). Among them, OYE2p from S. cerevisiae YJM1341 (GenBank Accession Number: AJV32222.1) showed relatively higher activity and higher enantioselectivity. Therefore, OYE2p was chosen for further studies.

A multiple sequence alignment revealed that the amino acid sequence of OYE2p from S. cerevisiae YJM1341 shared the identity of 99.3, 91.8, 81.3, 71.3, and $38.6 \%$ with the reported OYE2 from S. cerevisiae (GenBank Accession Number: Q03558.3), OYE1 from Saccharomyces carlsbergensis (GenBank Accession Number: Q02899.3), OYE3 from S. cerevisiae (GenBank Accession Number: CAA97878), KYE1 from K. lactis (Genbank Accession Number: L37452.1) and OYE2.6 from P. stipites (NCBI Accession Number: xp_001384055) (Fig. 1). OYE1, OYE2 and OYE3 could use both NADH and $\mathrm{NADPH}$ as the coenzymes. OYE1 and OYE3 preferably produced $(S)$-citronellal from $(E / Z)$-citral with the supply of NADH or NADPH, while OYE2 preferably produced 
Table 1 Screening of enoate reductases for citral reduction

\begin{tabular}{lllr}
\hline Enzyme & Sources of strains & Conversions (\%) & ee (\%) \\
\hline OYE2p & Saccharomyces cerevisiae YJM1341 & 97.2 & $84.5(R)$ \\
OYE3p & Saccharomyces cerevisiae YJM1133 & 95.8 & $41.3(R)$ \\
Hypothetical protein & Vanderwaltozyma polyspora DSM 70294 & 46.4 & $67.8(R)$ \\
HYE2 & Ogataea polymorpha & 97.6 & $25.5(R)$ \\
MgER & Meyerozyma guilliermondii & 93.5 & $11.7(R)$ \\
\hline
\end{tabular}

Reaction conditions: $5 \mathrm{mM}(E / Z)$-citral, $40 \mathrm{~g} / \mathrm{L}$ resting cells and $0.2 \mathrm{mM} \mathrm{NAD}{ }^{+}$were mixed in $1 \mathrm{~mL} P B S(200 \mathrm{mM}, \mathrm{pH} 7.4)$. The reactions were incubated at $30{ }^{\circ} \mathrm{C}$ and $300 \mathrm{rpm}$ for $10 \mathrm{~h}$

$(R)$-citronellal with very low enantioselectivity $(\leq 20 \%$ $e e)$ (Hall et al. 2010). OYE2p also accepted both NADH and NADPH with equal efficiency. The specific activities of the purified OYE2p toward $(E)$-citral were $0.317 \mathrm{U} / \mathrm{mg}$ with NADH as the cofactor and $0.309 \mathrm{U} / \mathrm{mg}$ in the presence of NADPH. Different from OYE1 and OYE3, OYE2p produced mainly $(R)$-citronellal with $84.5 \%$ ee with the supply of NADH in the reaction system (Table 1).

\section{Characterization of OYE2p}

OYE2p containing a C-terminal $\mathrm{His}_{6}$-tag was purified to homogeneity by nickel-affinity chromatography. The SDS-PAGE analysis of the soluble protein fractions showed a single band with an apparent molecular size of about $44 \mathrm{kDa}$ (Fig. 2, lane 5), which was in accordance with the calculated molecular mass based on the deduced amino acid sequence. The specific activity of purified enzyme was $0.28 \mathrm{U} / \mathrm{mg}$ toward $(Z)$-citral and $0.31 \mathrm{U} /$ $\mathrm{mg}$ toward $(E)$-citral under standard conditions, indicating that OYE2p has a slight preference for $(E)$-citral over (Z)-citral.

The purified OYE2p exhibited an optimal activity at $40{ }^{\circ} \mathrm{C}$, while the enzyme activity dropped rapidly over $45{ }^{\circ} \mathrm{C}$ with only $52 \%$ residual activity at $50{ }^{\circ} \mathrm{C}$ (Fig. 3a). OYE2p showed a pH optimum at 7.0-8.0 in PBS and more than $70 \%$ activity was retained between $\mathrm{pH} 6.6$ and 9.6, indicating that OYE2p had a relatively broad catalytic pH (Fig. 3b). However, the enzyme activity decreased sharply below pH 6.0 and completely lost activity at $\mathrm{pH}$ 4.6. Furthermore, compared with in acidic conditions, neutral to the slight alkaline conditions gave higher activity. The thermal stability of OYE2p was decreased with increasing temperature. The enzyme was stable at 4 , $30{ }^{\circ} \mathrm{C}$ but labile at $40,50{ }^{\circ} \mathrm{C}$, giving the half-life time values of $291,257,11$ and $2.6 \mathrm{~h}$ at $4,30,40$ and $50^{\circ} \mathrm{C}$, respectively (Fig. 3c), suggesting that OYE2p was quite stable under mild reaction conditions, albeit high temperatures resulted in a rapid loss of enzyme activity. To investigate the $\mathrm{pH}$ stability, OYE2p was incubated at $\mathrm{pHs}$ ranging from 5.0 to 9.0 at $4{ }^{\circ} \mathrm{C}$. As shown in Fig. 3d, the enzyme was active at $\mathrm{pH} 6.0-8.0$ and more than $50 \%$ activity was retained after $257-\mathrm{h}$ incubation. As expected, exposed to high acidity or alkaline conditions, OYE2p became unstable. The half-life time values of OYE2p at pH 5.0 and 9.0 were 101 and 169 h, respectively. Nevertheless, the stability of OYE2p was rather $\mathrm{pH}$-independent.

23 a, $\beta$-Unsaturated compounds bearing a aldehyde, ketone, imide, carboxylic acid and ester as electron-withdrawing group were selected to evaluate the substrate spectrum of OYE2p. As shown in Table 2, maleimide 1a, $N$-phenylmaleimide $\mathbf{2 a}$ and ketoisophorone $\mathbf{4 a}$, both bearing two activated carbonyl groups next to $\mathrm{C}=\mathrm{C}$ bond, were preferred substrates for OYE2p, while the highest specific activity was observed toward 1a. Compared to 1a-3a, OYE2p showed lower activities toward a, $\beta$-unsaturated ketones and aldehydes bearing a carbonyl group next to $\mathrm{C}=\mathrm{C}$ bond (3a, 5a-7a, $9 \mathbf{a}-17 \mathbf{a})$. The position of the methyl substituent at the $\mathrm{C}=\mathrm{C}$ bond turned out to be crucial: OYE2p showed a marked higher activity for 2-cyclopentenone 3a than carvone (5a, 6a). Similar phenomenon was observed for 2-pentenal 9a and 2-methyl-2-pentenal 12a. OYE2p displayed higher activity for $(S)$-(-)-perillyl aldehyde $7 \mathbf{a}$ and olefin aldehydes (9a-12a, 16a, 17a). OYE2p showed higher activity for aryl olefinic aldehydes compared with alkyl enals and gave the highest activity toward 16a. The specific activity decreased in following order 9a $>12 a>10 a>11 a$ with the increase of chain length. It was found that catalytic activity decreased in the following order $9 a>12 a, 10 a>13 a, 11 a>15 a>14 a$, indicating $a$ - or $\beta$-substituent possibly playing important roles in enzyme-substrate affinity. Both increasing the chain length and $\beta$-substituent probably resulted in that $(Z)$ citral (14a) and $(E)$-citral (15a) were rather modest substrates for OYE2p with 0.28 and $0.31 \mathrm{U} / \mathrm{mg}$, respectively. Like other enoate reductases, the existence of hydroxyl group on the substrates had negative influence on the activity of OYE2p, and quite low activities were detected for (S)-(-)-perillyl alcohol (8a) and cinnamyl alcohol (18a). In the presence of an additional electron-withdrawing group, $a, \beta$-unsaturated dicarboxylic acid (19a), a, $\beta$-unsaturated dicarboxylic diester (20a), fumaramide (21a), fumaric dinitrile (22a) and 2-butenenitrile (23a) were well accepted by OYE2p. 


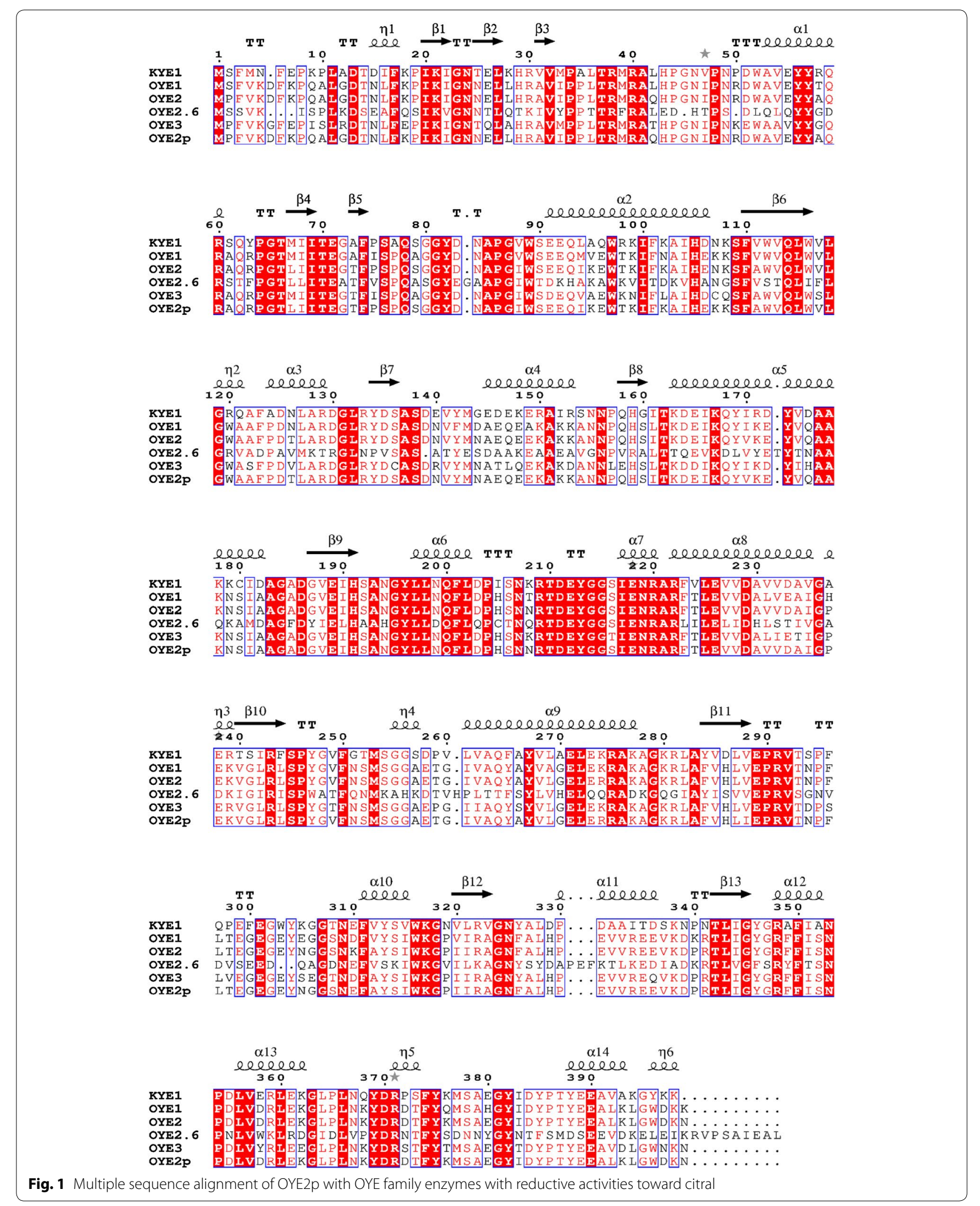




\begin{tabular}{|c|c|c|c|c|c|}
\hline \multirow[b]{2}{*}{ kDa } & 1 & 2 & 3 & 4 & 5 \\
\hline & & & & & \\
\hline 116.0 & 69 & & & & \\
\hline 66.2 & & & & & \\
\hline 45.0 & thes & & & & \\
\hline 35.0 & $\infty$ & & & men & \\
\hline 25.0 & ane & & & & \\
\hline 18.4 & ens & & & & \\
\hline 14.4 & inges & & & & \\
\hline $\begin{array}{l}\text { Fig. } 2 \text { SDS } \\
\text { weight ma } \\
\text { pET21d-OY } \\
\text { pET21d-OY } \\
\text { (DE3)/pET2 }\end{array}$ & $\begin{array}{l}\text { PAGE and } \\
\text { er; lane } 2 \\
2 p ; \text { lane } \\
2 p \text { lysate } \\
\text { d-OYE2R }\end{array}$ & & recip & $\begin{array}{l}\text { 2p. Lan } \\
\text { of E. co } \\
\text { E. coli } \\
\text { ractior } \\
\text { YE2p }\end{array}$ & $\begin{array}{l}\text { olecular } \\
\text { (DE3)/ } \\
\text { DE3)/ } \\
\text { cli BL21 }\end{array}$ \\
\hline
\end{tabular}

The enantioselectivity of OYE2p was measured against some substrates. As shown in Table 2, Ketoisophorone (4a) was a good substrate for OYE2p, but yielding the product $(R)$-levodione with a very low enantioselectivity of $25 \%$. (S)-carvone (6a) was reduced to $(2 R, 5 S)$-dihydrocarvone by OYE2p with high enantioselectivity of $98 \% d e$, while the reduction of $(R)$-carvone $(\mathbf{5 a})$ resulted in the $(2 R, 5 R)$-dihydrocarvone with low enantioselectivity $(74 \%$ de). OYE2p exhibited different enantioselectivity toward $(E)$-citral (15a) and (Z)-citral (14a), excellent enantioselectivity $(98.9 \% e e$, for $R$-isomer) was obtained toward $(E)$-citral, while low ee values of $26.5 \%$ toward $(Z)$-citral. For substrate 16a, OYE2p exhibited poor enantioselectivity (20\%ee, for $R$-isomer).

\section{Influence factor on enantioselectivity of OYE2p toward citral}

To develop more efficient synthetic process of $(R)$-citronellal, the low cost of citral (crude mixture of cis- and trans-isomer) makes it an attractive precursor. According to the literatures, the characterized enoate reductases exhibit varied selectivity patterns for $E$ - and $Z$-isomer with regard to the citral reduction. Accordingly, different $e e$ values of product may be obtained (Winkler et al. 2011; Hall et al. 2008, 2010; Bougioukou et al. 2010; Fryszkowska et al. 2009). There is no doubt enoate reductases with $R$-specific activity toward both $E$ - and $Z$-citrals are preferred. Based on the aforementioned results, OYE2p preferably produced $(R)$-citronellal from $(E / Z)$-citral (10:9 mixture of both isomers). A more detailed profile of citral isomer ratio on enantioselectivity of OYE2p was also investigated. As shown in Fig. 4, more $(R)$-citronellal was formed with increasing levels of $(E)$-citral in the substrate mixture. In general for $(E)$-citral and $(Z)$-citral, more $(R)$-citronellal was formed by OYE2p. At an $E / Z$ ratio of approximate $2 / 98$, a racemate was obtained with $e e$ value for $(R)$-citronellal of $25.3 \%$. It was quite different from OYE2 from $S$. cerevisiae which produced equimolar concentrations of citronellal enantiomers (Müller et al. 2007), albeit shared $99.3 \%$ identity of amino acid sequence with OYE2p. Three amino acid residues are different between OYE2p and OYE2, which are Lys108, Ile289, Glu311 in OYE2p and Asn108, Val289, Lys311 in OYE2. Based on the simulated structure of OYE1 from $S$. carlsbergensis (PDB ID: 3TX9) which shared $91.8 \%$ identity of amino acid sequence with OYE2p, ESPript online server (Robert and Gouet 2014) was used to draw the protein structure of OYE2p, and residues Lys108, Ile289 and Glu311 in OYE2p were found far away from the catalytic active center. With almost pure $(E)$-citral $(E / Z$ ratio of approximate $98 / 2)$, only $(R)$-citronellal was produced by OYE2p with excellent entioselectivity ( $>99.5 \% e e$ ), indicating that OYE2p was quite $R$-specific in the reduction of $(E)$-citral.

$\mathrm{pH}$ is often an important influence factor in biocatalysis, which can affect the structure of enzymes, binding of enzyme to substrate, as well as activity and stability of enzymes. Figure 3 shows that the activity of OYE2p was $\mathrm{pH}$-dependent. Herein, the effect of $\mathrm{pH}$ on substrate conversion and enantioselectivity for the OYE2p-catalyzed reduction of pure $(E)$-citral or $(Z)$-citral was investigated. As shown in Fig. 5a, for both citral isomers, the effect of $\mathrm{pH}$ on substrate conversion was quite similar. $\mathrm{pH}$ significantly affected citral bioconversion, and the highest conversion was obtained at $\mathrm{pH}$ 7.6. Compared with in acidic conditions, neutral to the slight alkaline conditions gave higher conversion. Furthermore, at $\mathrm{pH}$ values $<7.0$, substrate conversion decreased sharply, probably due to the decreased stability of OYE2p in acidic condition (Fig. 3d). These phenomena were identical to $\mathrm{pH}$ profile for activity of OYE2p (Fig. 3b). In general, OYE2p showed slightly higher conversion with $(E)$-citral at $\mathrm{pH} 5.0-10.0$ than with $(Z)$-citral. With pure $(E)$-citral, ee values of $(R)$-citronellal reached to $99 \%$ and were not affected by $\mathrm{pH}$. In contrast, with $(Z)$-citral, the $e e$ values of $(R)$-citronellal increased from 12.3 to $85.9 \%$ with the increase of $\mathrm{pH}$ from 5.0 to 10.0, but this trend was slight at $\mathrm{pH}$ 8.6-10.0. Considering that OYE2p was rather specific in reduction of $(E)$-citral to $(R)$-citronellal, one approach to achieve maximum $e e$ value for $(R)$-citronellal production with OYE2p would be the use of geometrically pure $(E)$-citral. When using $(E / Z)$-citral (10:9 mixture of $E$ - and $Z$-isomer) as substrate, the $e e$ values of $(R)$-citronellal were 

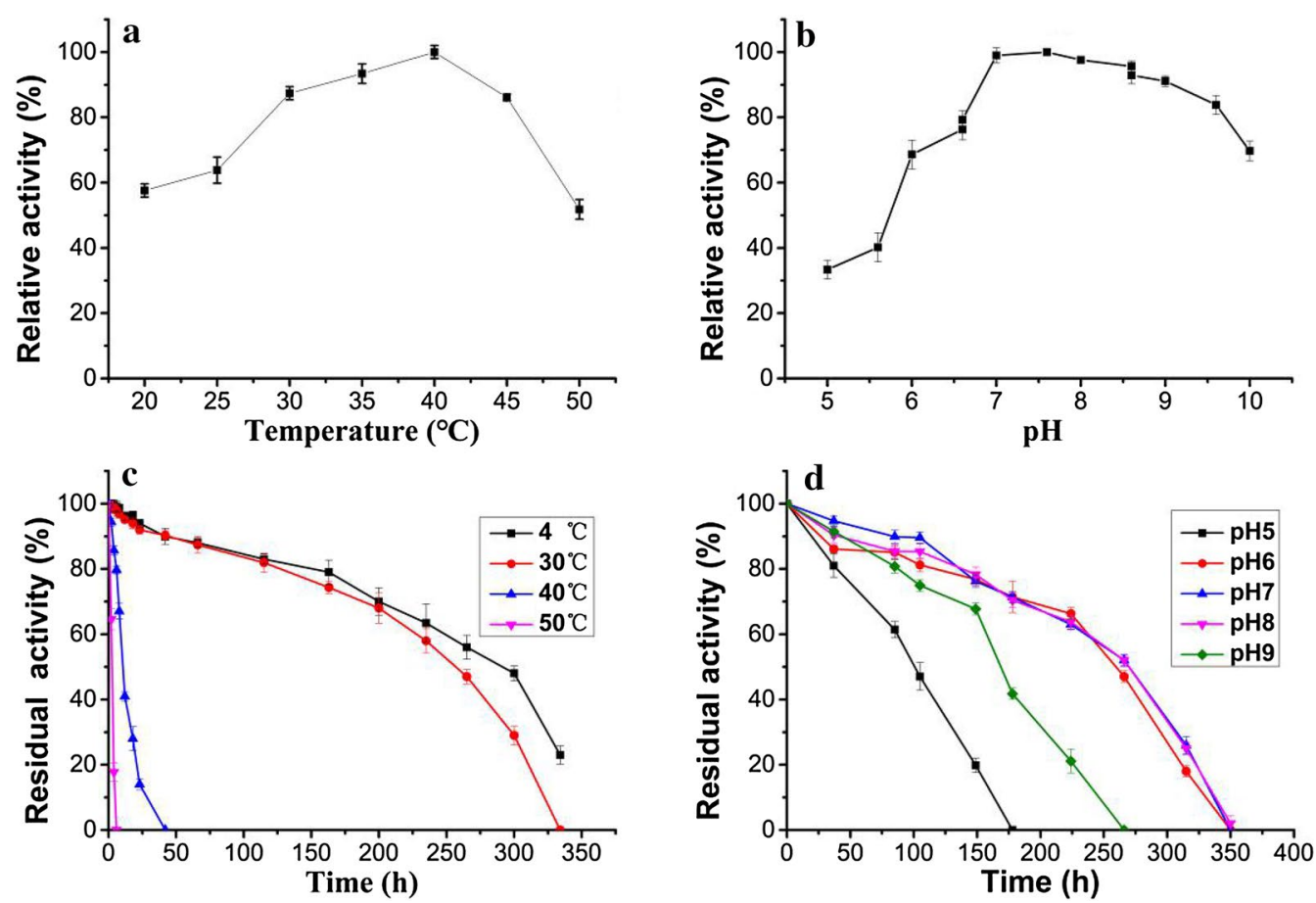

Fig. 3 Effects of temperature and pH on OYE2p activity and stability. a Activity-temperature profile. b Activity-pH profile. $200 \mathrm{mM}$ sodium citrate (pH 5.0-6.6), $200 \mathrm{mM}$ potassium phosphate (pH 6.6-8.6) and $200 \mathrm{mM}$ glycine-NaOH (pH 8.6-10.0) were used. c Thermal stability of OYE2p. OYE2p was incubated in PBS buffer ( $200 \mathrm{mM}, \mathrm{pH} 7.4$ ) at various temperatures. $4^{\circ} \mathrm{C}$ (filled square), $30^{\circ} \mathrm{C}$ (filled circle), $40^{\circ} \mathrm{C}$ (filled triangle) and $50^{\circ} \mathrm{C}$ (inverted filled triangle). $\mathbf{d}$ pH stability. OYE2p was incubated at $4^{\circ} \mathrm{C}$ in different $\mathrm{pH}$ buffer. $\mathrm{pH} 5$ (filled square), $\mathrm{pH} 6$ (filled circle), $\mathrm{pH} 7$ (filled triangle), $\mathrm{pH} 8$ (inverted filled triangle) and $\mathrm{pH} 9$ (filled rhombus)

increased from 21.4 to $92.6 \%$ with the increase of $\mathrm{pH}$ from 5.0 to 10.0 , while the increasing trend from $83.4 \%$ at $\mathrm{pH} 7.0$ to $92.6 \%$ at $\mathrm{pH} 10.0$ was not remarkable (Fig. 5b). It was also found that some citral isomerization occurred in alkaline conditions. When $\mathrm{pH}$ was changed from 7.0 (in PBS buffer) to 10.0 (in Gly- $\mathrm{NaOH}$ buffer), 9-17\% of added (Z)-citral was isomerized to $(E)$-citral in the absence of NADH and enzymes. Moreover, the isomerization remained constant after $6 \mathrm{~h}$. Under alkaline conditions in $\mathrm{Gly}-\mathrm{NaOH}$ buffer (pH 9.0-10.0), an equilibrium ratio between $E / Z$-isomers was reached an approximate ratio of 3:2. Isomerization of citral could be explained by Wolken et al. (2010). In the presence of glycine, and especially under alkaline conditions, the isomerization was probably catalyzed via transient Schiff's base formation between the aldehyde and glycine. The transient intermediate would be converted back into either $(E)$-citral or $(Z)$-citral, resulting in isomerization. In our results (Fig. 6), the isomerization of $(Z)$-citral to $(E)$-citral occurred with less $9 \%$ at $\mathrm{pH} 7.0$ and $14.2 \%$ at $\mathrm{pH} 8.0$ in PBS buffer, despite lack of amino acids or amino-groups of enzymes used as the catalyst. However, its mechanism has not yet been clear.

\section{Biotransformation of $(E / Z)$-citral to $(R)$-citronellal}

To demonstrate the utility of OYE2p for practical applications, the asymmetric reduction of $(E / Z)$-citral on a gram scale was performed using the recombinant OYE2p coupled with glucose dehydrogenase (BsGDH) from Bacillus megaterium that was used to regenerate NADH. From Fig. 5b, we concluded that the optimal pH of OYE2p was 8.6, at which the high substrate conversion and relatively high $e e$ value for $(R)$-citronellal could be achieved. The time course of the bioreduction of citral to citronellal is shown in Fig. 7. With the decrease of $(E)$-citral and $(Z)$-citral, the concentration of $(R)$-citronellal increased rapidly during the first $28 \mathrm{~h}$, and then, at a steadily rising velocity until $52 \mathrm{~h}$. During the reaction, the concentration of $(S)$-citronellal also increased at steady but slow velocity. And at the end of reaction, the amount of $(S)$-citronellal in the reaction system was approximately $10.35 \mathrm{mM}$. At the initial $8 \mathrm{~h}$ of reaction, $(E)$-citral decreased significantly faster compared with $(Z)$-citral. Then, the consumptions of $(E)$-citral and $(Z)$ citral were almost the same until $28 \mathrm{~h}$. $(E)$-citral was almost totally converted in $48 \mathrm{~h}$. After the reaction time of $52 \mathrm{~h}$, the reaction was almost completed with $98.4 \%$ 
Table 2 Substrate spectrum of OYE2p

\begin{tabular}{|c|c|c|c|c|}
\hline Substrate & Structure & No. & Specific activity (U/mg) & $e e(\%) /$ config. \\
\hline Maleimide & & $1 \mathbf{a}$ & 6.0 & - \\
\hline N-Phenylmaleimide & & $2 a$ & 4.24 & - \\
\hline 2-Cyclopentenone & & $\mathbf{3 a}$ & 2.49 & - \\
\hline Ketoisophorone & & $4 a$ & 3.05 & $25(R)$ \\
\hline (R)-Carvone & & $5 a$ & 0.54 & $74(2 R, 5 R)$ \\
\hline (S)-Carvone & & $6 \mathbf{a}$ & 0.7 & $98(2 R, 5 S)$ \\
\hline (S)-(-)-Perilla aldehyde & & $7 a$ & 2.71 & nd \\
\hline (S)-(-)-Perillyl alcohol & & $8 \mathbf{a}$ & 0.18 & nd \\
\hline 2-Pentenal & & $9 a$ & 2.04 & - \\
\hline Trans-2-hexenal & & $10 a$ & 1.58 & - \\
\hline 2-Octenal & & $11 a$ & 1.1 & - \\
\hline 2-Methyl-2-pentenal & & $12 a$ & 1.61 & nd \\
\hline 2-Isopropyl-5-methyl-2-hexenal & & $13 a$ & 0.98 & nd \\
\hline Neral & & $14 a$ & 0.28 & $26.5(R)$ \\
\hline Geranial & & $15 a$ & 0.31 & $98.9(R)$ \\
\hline a-Methylcinnamaldehyde & & $16 a$ & 2.96 & $20(R)$ \\
\hline Cinnamaldehyde & & $17 a$ & 2.53 & - \\
\hline
\end{tabular}


Table 2 continued

\begin{tabular}{|c|c|c|c|c|}
\hline Substrate & Structure & No. & Specific activity (U/mg) & ee (\%)/config. \\
\hline Cinnamylalcohol & & $18 a$ & 0.2 & - \\
\hline Fumaric acid & & $19 a$ & 1.1 & - \\
\hline Dimethyl maleate & & $20 a$ & 3.8 & - \\
\hline Fumaramide & & $21 a$ & 0.88 & - \\
\hline Fumaric dinitrile & & $22 a$ & 1.76 & - \\
\hline 2-Butenenitrile & $\mathbf{N} s$ & $23 a$ & 1.07 & - \\
\hline
\end{tabular}

Specific activities were determined at $30^{\circ} \mathrm{C}$ using $5 \mathrm{mM}$ substrate and $0.2 \mathrm{mM} \mathrm{NADH}$ in $200 \mathrm{mM} \mathrm{PBS}$ (pH 7.4) nd not determined

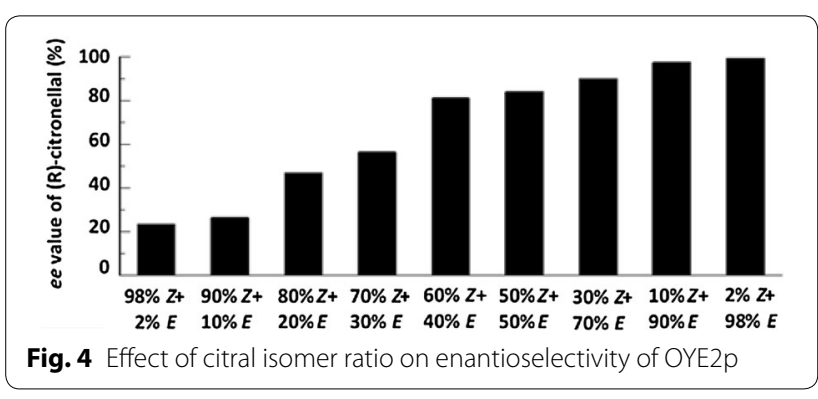

conversion, giving $(R)$-citronellal $(174.3 \mathrm{mM})$ in $87.2 \%$ yield and $88.8 \% e e$. To date, there are relatively few examples of employing enoate reductases for synthesis of optically $(R)$-citronellal on a gram scale, due to the shortage of $(R)$-enantioselective enoate reductases with high activity toward crude citral mixture. Bougioukou et al. developed the enzymatic strategy to produce gram-scale quantities of $(R)$-citronellal from pure $(E)$ citral, the substrate concentration reached to $150 \mathrm{mM}$ (Bougioukou et al. 2010). Although KYE1 from K. lactis could produce $(R)$-citronellal with $86 \%$ ee from $(E / Z)$ citral, the substrate concentration was only $10 \mathrm{mM}$ and conversion of $68 \%$ was very low (Yanto et al. 2011). By contrast, our work presented an efficient biocatalyst for the asymmetric reduction of $E / Z$-citral mixture to afford $(R)$-citronellal in high enantiopurity at relatively high substrate concentration.

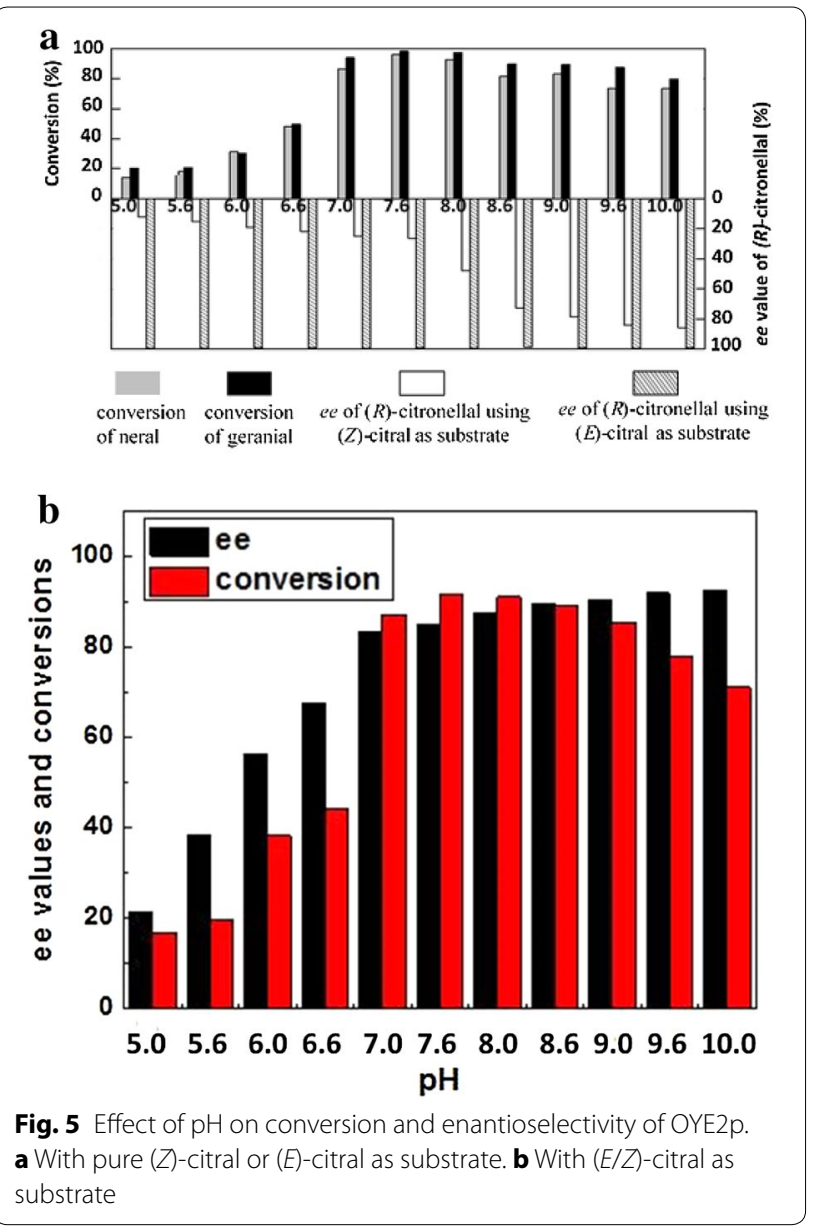




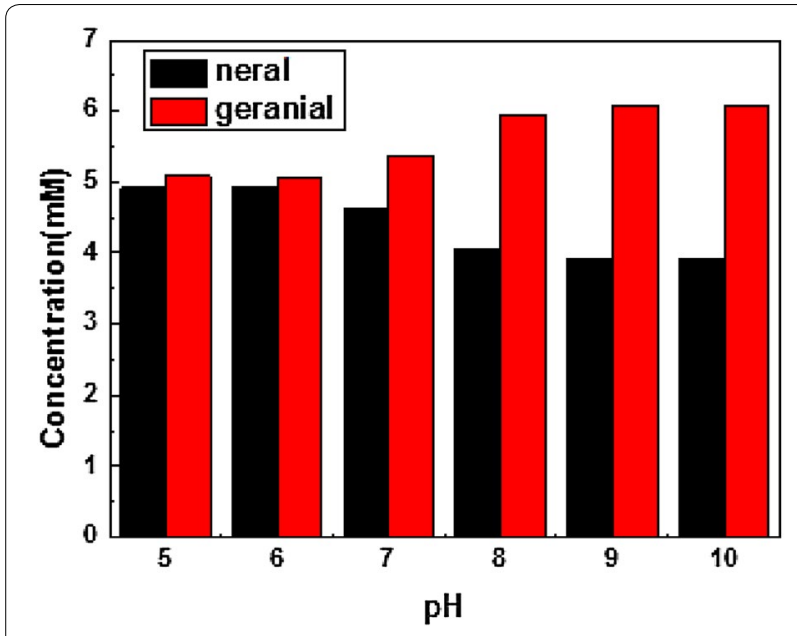

Fig. 6 Effect of $\mathrm{pH}$ on citral isomerization

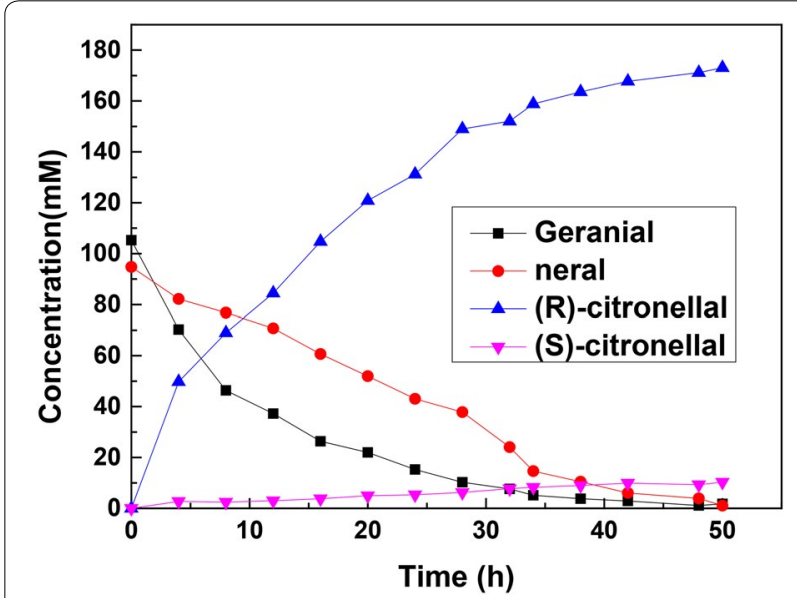

Fig. 7 Asymmetric reduction of (E/Z)-citral using purified OYE2p. Geranial (filled square), neral (filled circle), (R)-citronellal (filled triangle) and (S)-citronellal (filled inverted triangle)

\section{Conclusions}

A NAD(P)H-dependent enoate reductase (OYE2p) from S. cerevisiae YJM1341 was identified with relatively higher enantioselectivity on $(E / Z)$-citral mixture. This enzyme showed significant preference toward $a, \beta$ unsaturated aldehydes and ketones especially bearing two activating carbonyl groups next to $\mathrm{C}=\mathrm{C}$ bonds. OYE2p exhibited some eximious properties, such as a wide range of $\mathrm{pH}$ optimum and stability, as well as thermostability, made it very attractive for industrial applications. The selectivity pattern with regard to the $(E / Z)$-citral reduction by OYE2p was also studied in detail. The ee values for $(R)$-citronellal formation increased with the increasing levels of $E$-isomer in the $(E / Z)$-citral mixture as well as the increase of $\mathrm{pH}$. From this, an enzymatic strategy using OYE2p to produce gram-scale quantities of $(R)$-citronellal was developed, and as much as $200 \mathrm{mM}$ of $(E / Z)$ citral $(E / Z$ ratio $=10 / 9)$ could be asymmetrically reduced to $(R)$-citronellal in $88.8 \%$ ee and $87.2 \%$ yield. Further studies to design the desired complete $R$-selectivity for $(E / Z)$-citral by protein engineering are now in progress.

\section{Methods}

\section{Chemicals}

Citral (an approximately 10:9 mixture of $E$-isomer and $Z$-isomer), nerol, geraniol, $(R)$-citronellal and $(S)$-citronellal were purchased from Sigma-Aldrich (Shanghai, China). NADPH, NADH, NADP ${ }^{+}$and $\mathrm{NAD}^{+}$were purchased from Aladdin (Shanghai, China). All the other chemicals were ordered from Sinopharm Chemical Reagent Co., Ltd. (Z)-citral (neral) and (E)-citral (geranial) were obtained from Zhejiang NHU Co., Ltd (Zhejiang, China).

\section{Cloning and expression of enoate reductases}

Enoate reductase genes used for screening were selected from NCBI (https://www.ncbi.nlm.nih.gov/). Extraction and purification of genomic DNA were performed with TIANamp Bacteria DNA Kit (TIANGEN, Beijing, China). Plasmid DNA was extracted and purified using AxyPrep Plasmid Miniprep Kit 250-prep (AXYGEN, Jiangsu, China). The enoate reductase genes were amplified via PCR and ligated into the vector pET 21d (Novagen, Shanghai, China). All genes were sequenced to confirm the fidelity. The resultant plasmids were then introduced into the host $E$. coli BL21 (DE3) (TIANGEN, Beijing, China). The culture was started in a $5 \mathrm{~mL}$ LuriaBertani (LB) medium containing $50 \mu \mathrm{g} / \mathrm{mL}$ ampicillin. After shaking overnight at $37{ }^{\circ} \mathrm{C}$ and $300 \mathrm{rpm}$, the preculture was inoculated into $200 \mathrm{~mL}$ LB culture. When optical density at $600 \mathrm{~nm}$ reached to 0.6 , isopropyl- $\beta$-Dthiogalactoside (IPTG) was added to the culture (final concentration of $0.2 \mathrm{mM}$ ) to induce the expression of the enzymes at $20^{\circ} \mathrm{C}$ and $175 \mathrm{rpm}$ for $20 \mathrm{~h}$. Cells were harvested by centrifugation at $8000 \mathrm{~g}, 4{ }^{\circ} \mathrm{C}$ for $10 \mathrm{~min}$, and washed with $20 \mathrm{mM}$ phosphate buffer (PBS, pH 7.4).

\section{Screening of enoate reductases}

With probe enoate reductase KYE1 from $K$. lactis, BLASTp was carried out in NCBI database (http://www. ncbi.nlm.nih.gov), and proteins owning $\geq 30 \%$ identity of amino acid sequence were selected from different microorganisms. From these selected proteins, totally 11 OYE1 proteins, 26 OYE2p proteins, 13 OYE3p proteins as well as 19 hypothetical proteins were then selected according to the amino acid sequence of $(R)$-selective OYE1-3 in OYE family members. After heterogeneously 
overexpressed in E. coli BL21 (DE3), the activity and enantioselectivity toward $(E / Z)$-citral were determined.

The reaction system $(1 \mathrm{~mL})$ contained $200 \mathrm{mM}$ PBS (pH 7.4), $5 \mathrm{mM}(E / Z)$-citral, $40 \mathrm{~g} / \mathrm{L}$ wet cells and $0.2 \mathrm{mM}$ $\mathrm{NAD}^{+}$. After incubation at $30{ }^{\circ} \mathrm{C}$ and $300 \mathrm{rpm}$ for $10 \mathrm{~h}$, $2 \mathrm{~mL}$ ethyl acetate was added to the reaction mixture and the extracts were then determined by gas chromatograph (GC) to analyze conversions and $e e$ values.

\section{Purification of the recombinant OYE2 $p$}

The cell pellet was suspended in buffer A (20 mM PBS, $500 \mathrm{mM}$ sodium chloride, $25 \mathrm{mM}$ imidazole, $\mathrm{pH} 7.4$ ) and disrupted by an ultrasonic oscillator (JY92-II, Scientz Biotech. Ningbo, China). The cell debris was removed by centrifugation at $12,000 \mathrm{~g}, 4{ }^{\circ} \mathrm{C}$ for $30 \mathrm{~min}$. The supernatant was loaded onto a HisTrap HP 5-mL column (GE Healthcare, Beijing, China) pre-equilibration with buffer A. The target protein was eluted with an increasing gradient from 25 to $500 \mathrm{mM}$ of imidazole in PBS. The fractions containing the target protein were collected and dialyzed against $20 \mathrm{mM}$ PBS (pH 7.4) for desalting. The sample was concentrated and stored at $4{ }^{\circ} \mathrm{C}$, and SDS-PAGE was conducted to verify the expression and purification of OYE2p. The protein concentration was estimated with bicinchoninic acid (BCA) protein assay kit.

\section{Enzyme assay and characterization of OYE2p}

Enzyme activity was assayed at $30{ }^{\circ} \mathrm{C}$ by monitoring the decrease in the absorbance of NADH at $340 \mathrm{~nm}$ on an ultraviolet (UV)/visible spectrophotometer (BioTek Instruments, Inc. Vermont, USA). The molar extinction coefficient of $6.22 \mathrm{mM}^{-1} \mathrm{~cm}^{-1}$ for NADH was used for the calculation (Filling et al. 2002). Standard assay mixture $(200 \mu \mathrm{L})$ was composed of $200 \mathrm{mM}$ PBS (pH 7.4), $5 \mathrm{mM}$ alkene substrate, $0.2 \mathrm{mM} \mathrm{NADH}$, and an appropriate amount of purified enzyme. Reactions were performed in 96-well plates and initiated by addition of $\mathrm{NADH}$ and monitored for $2 \mathrm{~min}$. All the assays were conducted in triplicates. One unit of enzyme activity was defined as the amount of enzyme catalyzing the oxidation of $1 \mu \mathrm{mol} \mathrm{NADH}$ per minute after removal of background absorption.

The optimum temperature of OYE2p toward $(E)$-citral was determined under standard assay at different temperatures in a range of $25-60{ }^{\circ} \mathrm{C}$ with $5{ }^{\circ} \mathrm{C}$ intervals. The optimum $\mathrm{pH}$ was determined within a $\mathrm{pH}$ range of $5.0-10.0$ using various buffer systems at $200 \mathrm{mM}$ as follows: sodium citrate buffer for $\mathrm{pH}$ 5.0-6.6, PBS for $\mathrm{pH}$ 6.6-8.0, Gly- $\mathrm{NaOH}$ for $\mathrm{pH} 8.0-10.0$. For thermal stability determination, the enzyme was pre-incubated in PBS buffer (200 mM, pH 7.4) at varying temperatures of 4, 30, 40 and $50{ }^{\circ} \mathrm{C}$, and the residual activity was assayed under standard condition. The $\mathrm{pH}$ stability of OYE2p was evaluated by pre-incubating the purified enzyme in different $\mathrm{pH}$ buffers $(200 \mathrm{mM}, 5.0-9.0)$ at $4{ }^{\circ} \mathrm{C}$ for a varied period of time. Samples were taken for residual activity assay, with the non-incubated OYE2p as the control. To investigate the substrate spectrum, the specific activities of OYE2 $p$ toward a series of structurally diverse $a, \beta$-unsaturated compounds bearing a ketone, aldehyde, cyclic imide, and carboxylic ester were determined under standard conditions.

\section{Effects on enantioselectivity of OYE2 $p$ toward citral}

To test the effect of citral isomer ratio on enantioselectivity of OYE2p, $(E)$-citral and (Z)-citral were mixed in varied proportions $(98 \% Z+2 \% E, 90 \% Z+10 \% E, 80 \%$ $Z+20 \% E, 70 \% Z+30 \% E, 60 \% Z+40 \% E, 50 \% Z+50 \%$ $E, 30 \% Z+70 \% E, 10 \% Z+90 \% E, 98 \% E+2 \% Z)$. The reduction reaction was performed in $1 \mathrm{~mL}$ PBS buffer (200 mM, pH 7.6) supplemented with $5 \mathrm{mM}$ different ratio citral, $5.1 \mathrm{mM} \mathrm{NADH}$ and $0.2 \mathrm{U}$ purified OYE2p, at $30{ }^{\circ} \mathrm{C}, 300 \mathrm{rpm}$ for $6 \mathrm{~h}$. Samples were withdrawn, and enantiomer excess and conversion of substrate were determined by chiral GC analysis. To test the effect of $\mathrm{pH}$ on enantioselectivity of OYE2p, the reduction reaction was performed in different PBS buffer $(200 \mathrm{mM}$, pH 5.0-10.0) supplemented with $5 \mathrm{mM}$ pure $(E)$-citral or (Z)-citral, $5.1 \mathrm{mM} \mathrm{NADH}$ and $0.2 \mathrm{U}$ purified OYE2p at $30{ }^{\circ} \mathrm{C}, 300 \mathrm{rpm}$ for $4 \mathrm{~h}$.

To further investigate the isomerization between $E$ and $Z$-isomers of citral, trials were conducted in $1 \mathrm{~mL}$ mixture containing $10 \mathrm{mM}$ citral (10:9 mixture of $E$ - and $Z$-isomer) and $200 \mathrm{mM}$ buffers (pH $5.0-10.0)$ at $30{ }^{\circ} \mathrm{C}$, $300 \mathrm{rpm}$ for $6 \mathrm{~h}$. The thermodynamically isomerization under different $\mathrm{pH}$ was calculated by $\mathrm{GC}$ analysis.

\section{Enantioselective bioreduction of citral using purified OYE2p under appropriate $\mathrm{pH}$}

The bioreduction of citral was carried out in $100 \mathrm{~mL}$ PBS buffer (200 mM, pH 8.6) containing $200 \mathrm{mM}$ citral, $40 \mathrm{U}$ purified OYE2p, $35 \mathrm{U}$ glucose dehydrogenase from Bacillus subtilis (BsGDH), $0.2 \mathrm{mM} \mathrm{NAD}^{+}$and $240 \mathrm{mM}$ glucose. The mixture was incubated at $30{ }^{\circ} \mathrm{C}$ with stirring at $300 \mathrm{rpm}$. The $\mathrm{pH}$ value of the mixture during the reaction was monitored and adjusted to 8.0-9.0 using $1 \mathrm{M}$ $\mathrm{Na}_{2} \mathrm{CO}_{3}$ by a $\mathrm{pH}$ automatic regulator (CPA- $1 \mathrm{~A}$, Chroma, Changsha, China). Samples were collected at intervals and extracted twice with ethyl acetate. The combined organic layers were then analyzed by GC.

\section{Analytical methods}

The conversion of citronellal, nerol, neral (14a), geraniol and geranial (15a) was performed on GC system (GC, 7820A, Agilent) using HP-5 column (30 $\mathrm{m} \times 0.32 \mathrm{~mm} \times 0.25 \mu \mathrm{m}$, Aglient). Sample was $1 \mu \mathrm{L}$ 
with $\mathrm{N}_{2}$ as carrier gas $(1 \mathrm{~mL} / \mathrm{min})$ and a split ratio of 10:1. The injection and detector temperatures were 220 and $250{ }^{\circ} \mathrm{C}$, respectively. The temperature program involved $100{ }^{\circ} \mathrm{C}$ for $2 \mathrm{~min}$ followed by a $10{ }^{\circ} \mathrm{C} / \mathrm{min}$ increase to $150{ }^{\circ} \mathrm{C}$ for $4 \mathrm{~min}$. Under these conditions, the retention times of citronellal, nerol, neral, geraniol and geranial were $3.62,4.53,4.69,4.86$ and $5.01 \mathrm{~min}$, respectively.

The conversion and ee values of $(R)$-carvone $(5 \mathbf{a})$ and $(S)$-carvone $(\mathbf{6 a})$ were determined by GC using DB-5 column $(30 \mathrm{~m} \times 0.32 \mathrm{~mm} \times 0.25 \mu \mathrm{m}$, Aglient). The temperature program involved $90^{\circ} \mathrm{C}$ for $2 \mathrm{~min}$ followed by a $10{ }^{\circ} \mathrm{C} / \mathrm{min}$ increase to $200{ }^{\circ} \mathrm{C}$ for $2 \mathrm{~min}$. Under these conditions, the retention times of $(R)$-carvone, $(2 R, 5 R)$-dihydrocarvone and $(2 S, 5 R)$-dihydrocarvone were $7.9,7.3$ and $7.4 \mathrm{~min}$, respectively.

The $e e$ value of citronellal was determined by GC using Beta DEX 225 column $(30 \mathrm{~m} \times 0.25 \mathrm{~mm} \times 0.25 \mu \mathrm{m}$, Supelco) with split injection of 100:1. The temperature programs involved $95{ }^{\circ} \mathrm{C}$ for 35 min followed by a $5{ }^{\circ} \mathrm{C} / \mathrm{min}$ increase to $160{ }^{\circ} \mathrm{C}$ for $2 \mathrm{~min}$, then a $10^{\circ} \mathrm{C} / \mathrm{min}$ increase to $200{ }^{\circ} \mathrm{C}$ for $5 \mathrm{~min}$. Under these conditions, the retention times of $(S)$ - and $(R)$-citronellal were 24.9 and $25.1 \mathrm{~min}$, respectively. The $e e$ of levodione $(\mathbf{4 b})$ was determined by GC using a CP-ChiraSil-DEX CB column $(25 \mathrm{~m} \times 0.25 \mathrm{~mm} \times 0.25 \mu \mathrm{m}$, Varian) with split injection of 10:1. The temperature programs involved $95^{\circ} \mathrm{C}$ for $2 \mathrm{~min}$ followed by a $5{ }^{\circ} \mathrm{C} / \mathrm{min}$ increase to $110^{\circ} \mathrm{C}$ for $1 \mathrm{~min}$, then a $10{ }^{\circ} \mathrm{C} / \mathrm{min}$ increase to $180{ }^{\circ} \mathrm{C}$ for $2 \mathrm{~min}$. Under these conditions, the retention times of ketoisophorone (4a) and $(S)$ - and $(R)$-levodione were 5.9, 6.7 and $6.5 \mathrm{~min}$, respectively. The $e e$ of 2 -methyl-hydrocinnamaldehyde (16b) was determined by HPLC using a Chiralcel OJ-H column $(250 \mathrm{~mm} \times 4.6 \mathrm{~mm}, 5 \mu \mathrm{m}$, Daicel $)$ with $n$-hexane/2-propanol $(99: 1 \mathrm{v} / \mathrm{v})$ as eluting solvent; the retention times of $(R)$ - and (S)-2-methyl-hydrocinnamaldehyde and $\alpha$-methylcinnamaldehyde (16a) were 12.2 , 13.9 and $15.6 \mathrm{~min}$, respectively.

\section{Abbreviations \\ E. coli: Escherichia coli; OYE: old yellow enzyme; LB: lysogeny broth; PBS: phosphate buffer; SDS-PAGE: sodium dodecyl sulfate polyacrylamide gel electrophoresis; GDH: glucose dehydrogenase; FID: flame ionization detector; EWG: electron-withdrawing group.}

\section{Authors' contributions}

$L Z$ and $J L$ designed the experiments. LZ performed the experiments. $L Z$ and $J L$ drafted the manuscript. BZ and YK helped in the research experiments. $J \mathrm{~L}$ and $\mathrm{DW}$ conceived the research. All authors read and approved the final manuscript.

\section{Author details}

${ }^{1}$ State Key Laboratory of Bioreactor Engineering, New World Institute of Biotechnology, East China University of Science and Technology, Shanghai 200237, China. ${ }^{2}$ Department of Bioengineering, East China University of Science and Technology, Shanghai 200237, China.
Acknowledgements

Not applicable.

\section{Competing interests}

The authors declare that they have no competing interests.

Availability of data and materials

All data generated or analyzed during this study are included in this article.

\section{Consent for publication}

All authors have read and approved to submit it to Bioresources and Bioprocessing

\section{Ethics approval and consent to participate}

Not applicable.

\section{Funding}

This work was supported by the Natural Science Foundation of China (No. 21276084) and Shanghai Natural Science Foundation (No. 15ZR1408600).

\section{Publisher's Note}

Springer Nature remains neutral with regard to jurisdictional claims in published maps and institutional affiliations.

Received: 24 October 2017 Accepted: 31 January 2018

Published online: 22 February 2018

\section{References}

Akutagawa S (1997) Enantioselective isomerization of allylamine to enamine: practical asymmetric synthesis of (-)-menthol by Rh-BINAP catalysts. Top Catal 4:271-274

Amato ED, Stewart JD (2015) Applications of protein engineering to members of the old yellow enzyme family. Biotechnol Adv 33:624-631

Bergner EJ, Ebel K, Johann T, Löber O (2010) Method for the production of menthol. US Patent 7,709,688, 4 May 2010

Bougioukou DJ, Walton AZ, Stewart JD (2010) Towards preparative-scale, biocatalytic alkene reductions. Chem Commun 46:8558-8560

Filling C, Berndt KD, Benach J (2002) Critical residues for structure and catalysis in short-chain dehydrogenases reductases. J Biol Chem 277:25677-25684

Fryszkowska A, Toogood H, Sakuma M (2009) Asymmetric reduction of activated alkenes by Pentaerythritol tetranitrate reductase: specificity and control of stereochemical outcome by reaction optimisation. Adv Synth Catal 351:2976

Hall M, Stueckler C, Ehammer H (2008) Asymmetric bioreduction of C=C bonds using enoate reductases OPR1, OPR3 and YajM: enzyme-based stereocontrol. Adv Synth Catal 350:411-418

Hall M, Stueckler C, Hauer B (2010) Asymmetric bioreduction of activated C=C bonds using Zymomonas mobilis NCR enoate reductase and old yellow enzymes OYE 1-3 from yeasts. Eur J Org Chem 2008:1511-1516

Hollmann F, Arends IWCE, Holtmann D (2011) Enzymatic reductions for the chemist. Green Chem 13:2285-2314

Lenardao EJ, Botteselle GV, De Azambuja F (2007) Citronellal as key compound in organic synthesis. Tetrahedron 63:6671-6712

Maeda H, Yamada S, Itoh H (2012) A dual catalyst system provides the shortest pathway for L-menthol synthesis. Chem Commun 43:1772-1774

Moore JC, Pollard DJ, Kosjek B, Devine PN (2007) Advances in the enzymatic reduction of ketones. Acc Chem Res 40:1412-1419

Müller A, Hauer B, Rosche B (2007) Asymmetric alkene reduction by yeast old yellow enzymes and by a novel Zymomonas mobilis reductase. Biotechnol Bioeng 98:22

Richter N, Gröger H, Hummel W (2011) Asymmetric reduction of activated alkenes using an enoate reductase from Gluconobacter oxydans. Appl Microbiol Biotechnol 89:79-89

Robert X, Gouet P (2014) Deciphering key features in protein structures with the new ENDscript server. Nucleic Acids Res 42(Web Server issue):W320 
Stuermer R, Hauer B, Hall M (2007) Asymmetric bioreduction of activated C=C bonds using enoate reductases from the old yellow enzyme family. Curr Opin Chem Biol 11:203

Tani K (1985) Asymmetric isomerization of allylic compounds and the mechanism. Pure Appl Chem 57:1845-1854

Trasarti AF, Marchi AJ, Apesteguí ACR (2004) Highly selective synthesis of menthols from citral in a one-step process. J Catal 224:484-488

Winkler CK, Gábor T, Dorina C (2011) Asymmetric bioreduction of activated alkenes to industrially relevant optically active compounds. J Biotechno 162:38
Wolken WAM, Have RT, Werf MJVD (2010) Amino acid-catalyzed conversion of citral: cis-trans isomerization and its conversion into 6-methyl-5-hepten2-one and acetaldehyde. J Agric Food Chem 48:5401-5405

Yanto Y, Yu H, Hall M (2010) Characterization of xenobiotic reductase A (XenA): study of active site residues, substrate spectrum and stability. Chem Commun 46:8809

Yanto Y, Winkler CK, Lohr S (2011) Asymmetric bioreduction of alkenes using ene-reductases YersER and KYE1 and effects of organic solvents. Org Lett 13:2540

\section{Submit your manuscript to a SpringerOpen ${ }^{\circ}$ journal and benefit from:}

- Convenient online submission

- Rigorous peer review

- Open access: articles freely available online

- High visibility within the field

- Retaining the copyright to your article

Submit your next manuscript at $\boldsymbol{\nabla}$ springeropen.com 